\title{
POSTHARVEST ROTS OF AVOCADOS : IMPROVED CHEMICAL CONTROL BY USING DIFFERENT APPLICATION METHODS
}

\author{
K.R. EVERETT ${ }^{1}$ and L. KORSTEN ${ }^{2}$ \\ ${ }^{1}$ Horticulture and Food Research Institute of New Zealand, \\ Te Puke Research Centre, 412 No. 1 Road, RD2, Te Puke, New Zealand \\ ${ }^{2}$ Department of Microbiology and Plant Pathology, \\ University of Pretoria, Republic of South Africa
}

\begin{abstract}
Four methods of applying prochloraz to 'Fuerte' avocados postharvest were compared. These were: dipping, with and without a subsequent coating with polyethylene wax, ultra-low volume spray application followed by wax, and applying in wax. Prochloraz reduced rots best when applied as an ultra-low volume spray followed by waxing. It was also very effective when applied in wax. Dipping fruit in prochloraz increased the incidence of some types of rots. Waxing fruit without a prochloraz treatment reduced the incidence of internal and external stem end rots. This suggests that wax prevented stem end rot fungi from gaining entry to the fruit during packing.
\end{abstract}

Keywords: avocado, postharvest, prochloraz, diseases, wax

\section{INTRODUCTION}

Avocado (Persea americana) fruit are susceptible to postharvest anthracnose and stem end rots caused by species of Colletotrichum, Botryosphaeria, Fusicoccum, Fusarium and Phomopsis in both New Zealand and South Africa (Darvas and Kotze 1987; Hartill 1991). Despite commercially used pre- and postharvest chemical treatments, including prochloraz applied as a postharvest dip, New Zealand avocados still have unacceptably high levels of fruit decay due to postharvest diseases (Hopkirket al. 1994). In addition, under simulated commercial conditions, application of prochloraz as a postharvest dip has been observed to increase rots in some instances (unpublished data). Application of wax to apples improved fruit quality in storage, as assessed by firmness, colour and weight loss (Drake and Nelson 1990). Avocado fruit in South Africa is routinely waxed, but not treated with chemicals postharvest. South African fruit has lower levels of rots than New Zealand fruit (Everett and Korsten 1994). In an endeavour to improve control of postharvest rots of avocados, prochloraz was applied to avocado fruit using several application methods, some in combination with waxes.

\section{METHODS}

Ten trays per treatment ( $\mathrm{ca}$. 150 fruit) of 'Fuerte' avocado fruit were randomly removed from a commercial packing line at Everdon Estate, KwaZulu/Natal, South Africa. There were two control treatments: (1) fruit were coated with commercial Tag wax (polyethylene wax, 1 litre/tonne of fruit, ICI, Johannesburg, SA) and (2) one minute water dip. Prochloraz was applied (treatment 3 ) as an ultra low volume spray (ULV) (44 ml/litre, 1.6 litre/tonne of fruit, Omega 45\% a.i. E.C., FBC (Pty) Ltd, Chloorkop, SA) followed by drying at $50^{\circ} \mathrm{C}$ and waxing, or at the same rate $(44 \mathrm{ml} /$ litre) in the wax (treatment 4$)$. In treatment 5 , fruit were dipped ( $1.8 \mathrm{ml} /$ litre) then dried and in treatment 6 , fruit were dipped $(1.8 \mathrm{ml} / \mathrm{litre})$, then dried and waxed. After treatment fruit was packed and stored at $5.5^{\circ} \mathrm{C}$ for 28 days whereupon fruit was removed from the coolstore, placed at $c a .25^{\circ} \mathrm{C}$ and evaluated over two days when most fruit had ripened. Fruit was evaluated for softness on a $0-10$ scale $(0=$ hard, $5=$ ready to eat, $10=$ totally soft). Fruit was assessed internally and externally for stem

Proc. 49th N.Z. Plant Protection Conf. 1996: 37-40 
end rots, anthracnose and Dothiorella/Colletotrichum fruit rot complex (DCC). All assessments were made on a $0-10$ scale, $0=$ healthy and 10 indicating entire fruit decay (Korsten et al. 1995). For statistical analysis, data were analysed as two components, incidence and severity. Binomial data (incidence) were arcsine transformed and analysed using two way analysis of variance and means were separated by Fisher's protected least significant difference test. The fruit with rots (severity) was similarly analysed but data were not transformed. The incidence and severity of internal DCC was too low for this analysis and the data are not presented.

\section{RESULTS}

Prochloraz was most effective at controlling all postharvest diseases when applied either in wax (treatment 4 in Table 1) or as an ultralow volume application followed by waxing (treatment 3 in Table 1). The ultra-low volume application was most effective at reducing the severity of external anthracnose, and prochloraz in wax was most effective at reducing the incidence of external anthracnose. Both methods were equally effective in reducing severity of external stem end rots, internal anthracnose and the incidence of external stem end rots, internal anthracnose and external DCC. Severity of internal and external stem end rots and internal anthracnose was worse in the two dipping treatments than in controls. Dipping in prochloraz reduced severity of external anthracnose, but application of wax as well negated this reduction. Dipping in prochloraz also reduced incidence of DCC and external anthracnose. Incidence of external stem end rots was not reduced by dipping fruit in prochloraz, but was reduced when prochloraz was applied using treatment 3, ULV + wax and treatment 4, prochloraz in wax. Application of wax by itself reduced the incidence of external and internal stem end rots when compared with water-dipped control fruit, and increased incidence of DCC. Application of prochloraz as an ULV spray or in wax reduced the incidence of external and internal stem end rots further than wax alone. Application of wax by itself had no effect on softness when compared with water controls.

TABLE 1: Fruit softness, severity and incidence of postharvest rots on 'Fuerte' avocado fruit following different postharvest treatments.

\begin{tabular}{|c|c|c|c|c|c|c|}
\hline \multirow[b]{2}{*}{ Treatment } & \multirow[b]{2}{*}{$\begin{array}{c}\text { Fruit } \\
\text { softness }\end{array}$} & \multicolumn{2}{|c|}{ External rots } & \multirow{2}{*}{$\begin{array}{l}\text { Severity } \\
\text { DCC }^{2}\end{array}$} & \multicolumn{2}{|c|}{1 Internal rots } \\
\hline & & anthracnose & $\begin{array}{l}\text { stem } \\
\text { end }\end{array}$ & & anthracnose & $\begin{array}{l}\text { stem } \\
\text { end }\end{array}$ \\
\hline 1. wax only & $4.6 \mathrm{c}$ & $3.3 \mathrm{a}$ & $2.5 b$ & $1.8 \mathrm{a}$ & $2.6 \mathrm{~b}$ & $2.0 \mathrm{c}$ \\
\hline 2. water dip & $4.6 \mathrm{c}$ & $3.0 \mathrm{a}$ & $2.6 b$ & $2.2 \mathrm{a}$ & $2.3 b$ & $2.2 \mathrm{c}$ \\
\hline 3. ULV+ wax & $4.2 \mathrm{~d}$ & $1.4 \mathrm{c}$ & $1.6 \mathrm{c}$ & $1.2 \mathrm{a}$ & $1.5 \mathrm{c}$ & $1.6 \mathrm{c}$ \\
\hline 4. prochloraz in wax & $4.7 \mathrm{c}$ & $2.1 b$ & $1.8 \mathrm{c}$ & $2.2 \mathrm{a}$ & $2.0 \mathrm{bc}$ & $1.8 \mathrm{c}$ \\
\hline 5. prochloraz dip & $5.9 \mathrm{a}$ & $2.3 b$ & $3.2 \mathrm{a}$ & $1.0 \mathrm{a}$ & $3.5 \mathrm{a}$ & $5.9 \mathrm{a}$ \\
\hline 6. prochloraz dip + wax & $5.5 b$ & $3.0 \mathrm{a}$ & $3.6 \mathrm{a}$ & $2.1 \mathrm{a}$ & $3.8 \mathrm{a}$ & $4.5 b$ \\
\hline \multicolumn{7}{|l|}{ Incidence $^{4}$} \\
\hline 1. wax only & $4.6 \mathrm{c}$ & $1.2 \mathrm{a}$ & $0.7 \mathrm{~b}$ & $0.9 \mathrm{a}$ & $1.0 \mathrm{a}$ & $0.9 \mathrm{c}$ \\
\hline 2. water dip & $4.6 \mathrm{c}$ & $1.1 \mathrm{a}$ & $1.1 \mathrm{a}$ & $0.6 b$ & $0.9 \mathrm{a}$ & $1.1 \mathrm{ab}$ \\
\hline 3. ULV+ wax & $4.2 \mathrm{~d}$ & $0.6 \mathrm{c}$ & $0.4 \mathrm{c}$ & $0.3 \mathrm{c}$ & $0.5 b c$ & $0.4 \mathrm{~d}$ \\
\hline 4. prochloraz in wax & $4.7 \mathrm{c}$ & $0.5 \mathrm{~d}$ & $0.3 \mathrm{c}$ & $0.3 \mathrm{c}$ & $0.4 \mathrm{c}$ & $0.4 \mathrm{~d}$ \\
\hline 5. prochloraz dip & $5.9 \mathrm{a}$ & $0.9 \mathrm{~b}$ & $1.1 \mathrm{a}$ & $0.3 \mathrm{c}$ & $0.4 b c$ & $1.2 \mathrm{a}$ \\
\hline 6. prochloraz dip + wax & $5.5 b$ & $0.9 b$ & $0.8 \mathrm{~b}$ & $0.3 \mathrm{c}$ & $0.6 b$ & $1.0 \mathrm{bc}$ \\
\hline
\end{tabular}

Details of treatments are referred to in the text. Means in each column followed by the same letter were not significantly different according to Fisher's protected LSD test $(\mathrm{P}=0.05) .{ }^{1}$ Severity data is assessed on a $0-10$ scale; $0=$ healthy and 10 indicating entire fruit decay. Only fruit with rots were included in the analysis of severity. ${ }^{2} \mathrm{DCC}=$ Dothiorella/Colletotrichum complex. Incidence of internal DCC was too low for this analysis and the data are not presented. ${ }^{3} \mathrm{ULV}=$ ultra low volume. ${ }^{4}$ Incidence data are arcsine transformed. 


\section{DISCUSSION}

Ultra low volume application of fungicides requires higher concentrations of chemicals to be used in order to be effective (Knights 1986). In this experiment, both methods in which higher concentrations of prochloraz were used were more effective than all other methods in reducing postharvest rots. Further experimentation is required to investigate if the same effect applies if less prochloraz is used. Persistent use of high concentrations of prochloraz may encourage the development of a population of postharvest rot fungi resistant to this chemical so the use of the lowest effective rate should be recommended.

Hopkirk et al. (1994) showed that when fruit was assessed at the same ripeness, there was a correlation between rate of ripening and severity of rots; fruit that ripened slowly had more rots than fruit which ripened rapidly. In this study fruit which ripened most rapidly (prochloraz dipped fruit) had a lower incidence of external anthracnose and lower severity of both internal and external anthracnose rots than did controls despite being assessed when fruit were significantly softer than fruit in all other treatments. Those fruit which ripened least rapidly (wax only, water dipped, prochloraz in wax) had levels of rots more consistent with the treatment than the degree of ripeness. It therefore seems unlikely that assessing fruit at the same degree of ripeness will alter the results obtained in the present study.

Prochloraz applied as a dip appeared to increase the incidence and severity of some rots. When prochloraz was applied as a dip it also increased the rate of ripening as assessed by softness of fruit (treatment 5 and treatment 6 in Table 1). According to Hopkirk et al. (1994), an increase in the rate of ripening decreases the amount of rot, contrary to the results obtained here. Low concentrations of some fungicides actually encouraged growth of Alternaria tenuissima in agar (Everett and Neilson 1996). It is possible that the chemicals provide nutrients which encourage growth of these fungi. Application of wax to prochloraz dipped fruit significantly delayed ripening, although when prochloraz was applied at high rates in wax, softness was not different to controls. Application of wax by itself had no effect on softness of fruit in contrast to the results of Drake and Nelson (1990) in which wax was applied to apples. Therefore it is unclear why wax applied to prochloraz dipped fruit delayed ripening.

Application of wax by itself to avocado fruit reduced the incidence of both external and internal stem end rots. It is possible that the effect was because the fruit was dry, not because the fruit was waxed. Moisture on the surface of all other fruit, except the prochloraz in wax treatment, may encourage sporulation and infection with these fungi. However, when wax was applied to fruit which had been prochloraz dipped, which by itself did not reduce stem end rots, these rots were reduced by the same degree as fruit which had only been waxed. This tends to suggest that it was the application of wax which reduced the incidence of stem end rots, and also suggests that infection with these fungi takes place immediately after harvest. In contrast, wax application increased the incidence of DCC. The DCC fungi may already be present on fruit at harvest, or as latent infections. Waxing may provide a humid environment which encourages these fungi to resume growth.

\section{ACKNOWLEDGEMENTS}

Estelle Towsen, Marius Borshoff and staff of Everdon Estate, KwaZulu/Natal, South Africa, and to Nihal deSilva for statistical advice.

\section{REFERENCES}

Darvas, J.M. and Kotze, J.M., 1987. Fungi associated with pre- and postharvest diseases of avocado fruit at Westfalia Estate, South Africa. Phytophylactica 19: 83-85.

Drake, S.R. and Nelson, J.W., 1990. Storage quality of waxed and nonwaxed 'Delicious' and 'Golden Delicious' apples. J. Food Qual. 13: 331-341.

Everett, K.R. and Korsten, L., 1994. Comparing the South African and New Zealand avocado industries. The N.Z. Avo. Growers Assn. Inc. Scientific Research and Technical Supplement 20: 39-47. 
Everett, K.R. and Neilson, H.F., 1996. Evaluation of fungicides for control of Alternaria leaf spot of Pseudopanax. N.Z. J. Crop Hort. Sci.: (in press).

Hartill, W.F.T., 1991. Post-harvest disease of avocado fruits in New Zealand. N.Z. J. Crop Hort. Sci. 19: 297-305.

Hopkirk, G., White, A., Beever, D.J. and Forbes, S.K., 1994. Influence of postharvest temperatures and the rate of fruit ripening on internal postharvest rots and disorders of New Zealand 'Hass' avocado fruit. N.Z. J. Crop Hort. Sci. 22: 305311.

Korsten, L., De Jager, E.S., De Villiers, E.E., Kotze, J.M. and Wehner, F.C., 1995. Evaluation of bacterial epiphytes isolated from avocado leaf and fruit surfaces for biocontrol of avocado postharvest diseases. Plant Dis. 79: 1149-1156.

Knights, I.K., 1986. Developments in the use of prochloraz for tropical fruit disease control. Proc. British Crop Prot. Conf:: 331-335. 